Zoology at Durham :

Prof. D. Barker

Prof. David Barker has been appointed to the chair of zoology in the Durham Division of the University of Durham, succeeding Prof. J. B. Cragg, who resigned in order to take up a senior post with the Nature Conservancy (Nature, 190, 488; 1961). Prof. Barker went up to Magdalen College, Oxford, in 1941, and, after being awarded a Jenner Exhibition, graduated in zoology with first-class honours in 1943. In 1946 he was appointed to a Senior Demyship at Magdalen College and obtained a Leverhulme Research Scholarship at the Royal College of Surgeons. In 1948 he graduated D.Phil. with a thesis entitled "The Recovery of Proprioceptor Function after Nerve-injury". In this year he was awarded the Rolleston Memorial Prize. He was appointed to the chair of zoology in the University of Hong Kong in 1950. At Hong Kong Prof. Barker, as head of the Department of Biology (which has since divided into two Departments), was confronted with many responsibilities, the organization of courses from the most elementary up to the special honours level in zoology and extra-mural work. It is also remarkable that he found time to organize and direct a most successful Fisheries Research Unit equipped with its own laboratory and research vessel. Prof. Barker's main interests lie in the field of proprioception; he has recently organized an international symposium on muscle receptors in connexion with the golden jubilee of the University of Hong Kong. He has a great interest in field work as is shown by his leadership of expeditions to North Borneo and (1950) to Tunisia, in the latter case to investigate the remarkable hot-spring crustacean Thermosbaena mirabilis. Prof. Barker is a man of wide and extremely varied talents and great energy and will undoubtedly make his mark in his new post.

Humber Laboratory, Hull :

Dr. G. H. O. Burgess

Dr. G. H. O. Buraess has been appointed officerin-charge of the Humber Laboratory, Hull, in succession to Dr. C. L. Cutting, who has now been appointed director of research, British Food Manufacturing Industries' Research Association at Leatherhead (Nature, 193, 219; 1962). The Humber Laboratory was established in 1950 by the Department of Scientific and Industrial Research to deal specifically with the problems of the Humber-based fish industry. Dr. Burgess, who is thirty-five, having obtained an honours B.Sc. at the University of Reading, worked between 1951-54 on a problem connected with fish at the University of Hull, under a contract placed by the Department of Scientific and Industrial Research, and was awarded the degree of Ph.D. of the University of London. He joined the Humber Laboratory, Hull, in 1954. In 1959 he was transferred to Torry Research Station, Aberdeen, to take on overall responsibility for obtaining information about the fish industry.

\section{The Royal Society}

IN the House of Commons on January 25, Mr. H. Brooke, Chief Secretary to the Treasury, said that his officials had been approached by the Royal Society about the possibility of accommodation for the Society in Carlton House Terrace and that the Society had been informed that it would be difficult to go beyond the offer of additional accommodation in Burlington Gardens which the Government had already made to the learned societies. When Mr. A.
Albu urged that the Royal Society was badly in need of more space than it had in its present premises and asked if the Government would go further and provide a real scientific centre, Mr. Brooke added that the learned societies, including the Royal Society, already occupied nearly 68,000 sq. ft. of Government accommodation rent free and were shortly to be provided in Burlington Gardens with further accommodation which would increase the total to nearly 89,000 sq. ft. and that he did not think the Government could be criticized for parsimony here.

\section{Publication of Industrial Research in the United States}

THe National Science Foundation has carried out a study to show the publication policies and practices of 174 companies performing relatively large amounts of basic research during the period 1957-59 (NSF 61-62. Pp. vi +43. Washington, D.C.: Government Printing Office, 1961. 25 cents). The report reveals that companies with liberal policies concerning publication feel that publication of basic research findings increases the prestige of their companies, facilitates their recruitment of scientists and engineers, and improves staff morale. On the other hand, a number of companies stated that premature release of basic research information may be disadvantageous to the interests of their companies. When competitive considerations are involved, basic research findings may be delayed or withheld from publication. Nearly all the companies indicated that there was a clearance procedure for the publication of basic research papers prepared by their scientists and engineers. Many companies encouraged the publication of papers written by their scientific staff by providing services to assist the author in preparation of his paper. The annual volume of basic research papers originating from the 174 companies increased appreciably during 1957-59. The total of 3,310 basic research papers prepared in 1959 was 23 per cent higher than the 2,700 for 1958 , and 45 per cent higher than the 2,290 reported for 1957. Companies with large expenditure for basic research accounted for a major share of the basic research papers reported by the 174 companies. The eight companies which expended 5 million dollars or more for basic research accounted for 1,450 papers in 1959 , or 44 per cent of the total. On the other hand, 39 companies with funds for carrying out basic research, ranging between 50,000 and 99,000 dollars, reported 150 papers, or 5 per cent of the total.

\section{French Study Centre for Small and Medium-sized Firms}

A "Centre of Technical, Economic and Social Studies and Projects for Small and Medium-sized Firms" has been set up in France. The Centre will provide firms with a number of technical, economic and finanoial services to help them to prepare longterm expansion programmes and give the technical data they need for carrying out these plans. The Centre provides three types of services-technical, financial and economic. Technical services cover all technical problems concerning the firm, such as selection, wage-rates, output and production capacity of plant and equipment. Financial services include the financial structure of the firm, its financial problems and credit transactions, whether short, medium or long-term. It compiles dossiers to be submitted to banking and credit establishments. In 